Macedonian Pharmaceutical Bulletin, 66 (Suppl 1) 207 - 208 (2020)

Online ISSN 1857 - 8969

UDC: $615.2: 347.771]: 340.13(4-672 \mathrm{EY})$

DOI: 10.33320/maced.pharm.bull.2020.66.03.103

Short communication

\title{
Changes in intellectual property systems in Commonwealth of Independent States and their harmonization within Eurasian Economic Union
}

\author{
Marija Mitkovska ${ }^{1}$, Katerina Anchevska Netkovska ${ }^{2}$, Ana Poceva Panovska ${ }^{2}$ \\ ${ }^{1}$ Alkaloid AD Skopje, Blvd. Aleksandar Makedonski 12, 1000 Skopje, North Macedonia \\ ${ }^{2}$ Faculty of Pharmacy, Ss. Cyril and Methodius University, Mother Teresa 47, 1000 Skopje, North Macedonia
}

\section{Introduction}

Intellectual property aspects, predominantly patent rights and data exclusivity, directly influence to access of medicines. Considering this, EU and USA have well balanced intellectual property systems (IPSs). In comparison with Commonwealth of Independent States (CIS) and Eurasian Economic Union (EAEU), the situation is opposite. CIS have constantly fluctuating IPSs, where some of the countries are implementing EU directives, and others are moving towards US IPS. On the other hand, EAEU is moving towards unifying the laws of intellectual property and medicines, thus arising the needs of harmonization the national laws of the member states.

In this article, we put focus on data exclusivity and patent linkage systems in the member states of EAEU and within EAEU.

\section{Materials and methods}

\section{Method 1 Patent linkage and data exclusivity review}

Analysis and comparison of regional regulation of EAEU and national legislations of the member states using the EAEU Rule and national patent laws and laws of medicine.

\footnotetext{
*mnikova@alkaloid.com.mk
}

\section{Results and discussion}

Data exclusivity, as a power intellectual property right, gives originators data protection of pre-clinical and clinical trials data for a certain period, which differs among countries. During this period, national authorities are forbidden to accept generic applications. In some jurisdictions, additionally to data exclusivity, is given a market exclusivity period. During the period of market exclusivity, submission of generic applications is permitted, only the launch of the generic products is forbidden (McKenzie, 2019; Хабриева, 2019). Generally, member states of World Trade Organization (WTO) are obliged to implement this provision on a national level (Хабриева, 2019).

Patent linkage is a practice of linking the marketing approval procedure for a generic medicinal product to the status of a patent of the originator reference product. Patent linkage system differs among countries. The health authorities, depending on the jurisdiction in question, may refuse the application, refuse to grant a marketing authorization, inform the patent owner to enable it to take any relevant action, etc. As a part of the registration dossier, among other administrative documents, a non-infringement statement has to be submitted (McKenzie, 2019). 
Armenia has implemented data exclusivity regime, giving originators 8 years of data exclusivity and 2 years of market exclusivity from the first marketing authorization of the originator product in Armenia or in a member state of the international professional organization established by the Government (The Republic of Armenia Law, 2016). Following the EU regime, the patent linkage provision was abandoned last year in June.

Belarus is a country which is still not a member state of WTO. Therefore, data exclusivity regime is not implemented in the legislation (ICO East Europe and Central Asia Union of PLWH, 2013; Хабриева, 2019). On the other hand, patent linkage provision is implemented in a non-typical way. A noninfringement statement letter is a part of the registration dossier, but the health authorities are not obliged to control the validity of those statements. In case of noticing that the registration dossier contains false information, the health authorities may decide to suspend the registration procedure/issued certificate for not more than 6 months (ICO East Europe and Central Asia Union of PLWH, 2013).

Kazakhstan has adopted data exclusivity in November 2015, so the national legislation could be aligned with WTO agreements. The data exclusivity period for an originator product is 6 years from the date of the first marketing authorization in the country (Abylkhanova, 2018; Хабриева, 2019). Before adopting data exclusivity, there was a good practice of the Kazakh patent linkage system. After November 2015, there is no longer a clear-cut situation regarding the implementation of the patent linkage system (McKenzie, 2019).

Kyrgyzstan has abolished the patent term extension, so the patents will be valid maximum for a 20 years period from the submission of the patent application (Lidings, 2020). Currently, data exclusivity and patent linkage system are not implemented in the national legislation (MeTA Secretariat Kyrgyz Republic, 2012).

Russia has implemented data exclusivity in 2014 (final provision introduced on $1^{\text {st }}$ of January 2016), giving originators a 4 years of data exclusivity and 2 years of market exclusivity from the first marketing authorization of the originator product in Russia (Хабриева, 2019). In January 2020 is announced that, a patent linkage system, as the USA system, is going to be implemented (Lidings, 2020).
EAEU has adopted data exclusivity provision. The data exclusivity period is 5 years from the first marketing authorization of the originator product within the union and 1 year of market exclusivity. Patent linkage system is also applicable within EAEU. In the registration dossier would have to be included information on the patents protecting the generic drug and a non-infringement statement (Совета ЕЭК, 2016). Additionally, within EAEU, a unified patent system is going to be introduced (Lidings, 2020).

Starting from 2021, national marketing authorizations of the EAEU member states will be abandoned. There will be the possibility only for regional marketing authorization of the drugs within EAEU (Совета ЕЭК, 2016).

\section{Conclusion}

There is inconsistency between the national legislations of the EAEU member states and the regional regulation of EAEU in terms of data exclusivity and patent linkage. It is obvious that EAEU regulation moves towards US patent system. Since starting from 2021 only regional marketing authorizations will be possible within EAEU, it is necessary to make amendments of the national laws of EAEU member states to be align with the supranational regulation of EAEU.

\section{References}

Abylkhanova, Z., 2018. Institute of "Data Exclusivity" in Kazakhstan and its Influence on Activity of Pharmaceutical Companies.

ICO East Europe and Central Asia Union of PLWH, 2013. Implementation of TRIPS Public Health Flexibilities to improve Access to Medicines in Belarus, Georgia, Moldova and Ukraine, pp. 43-48.

Lidings, 2020. Patent Disputes in Life Sciences.

McKenzie, B., 2019. Global Guide to Patent Linkage, pp. 2-5, 92-96.

MeTA Secretariat Kyrgyz Republic, 2012. Kyrgyzstan Pharmaceutical Country Profile, pp.12.

The Republic of Armenia Law, 2016. Law on Medicinal Products, Article 16.

Совета ЕЭК, 2016. Решение №78 О Правилах регистрации и экспертизы лекарственных средств для медицинского применения.

Хабриева Т., 2019. Без Права передачи.

Maced. Pharm. Bull. 66 (Suppl 1) 207 - 208 (2020) 